\title{
Transcriptome profiling reveals activation of inflammation and apoptosis in the neonatal striatum after deep hypothermic circulatory arrest
}

\author{
Lan N. Tu, PhD, ${ }^{\mathrm{a}, \mathrm{b}}$ Andrew E. Timms, PhD, ${ }^{\mathrm{b}}$ Nataliya Kibiryeva, $\mathrm{PhD},{ }^{\mathrm{c}}$ Douglas Bittel, $\mathrm{PhD},{ }^{\mathrm{c}, \mathrm{d}}$ \\ Anna Pastuszko, $\mathrm{PhD},{ }^{\mathrm{e}}$ Vishal Nigam, $\mathrm{MD},{ }^{\mathrm{a}, \mathrm{b}}$ and Peter Pastuszko, $\mathrm{MD}^{\mathrm{f}}$
}

\begin{abstract}
Objectives: Brain injury, leading to long-term neurodevelopmental deficits, is a major complication in neonates undergoing cardiac surgeries. Because the striatum is one of the most vulnerable brain regions, we used mRNA sequencing to unbiasedly identify transcriptional changes in the striatum after cardiopulmonary bypass and associated deep hypothermic circulatory arrest.
\end{abstract}

Methods: Piglets were subjected to cardiopulmonary bypass with deep hypothermic circulatory arrest at $18^{\circ} \mathrm{C}$ for 30 minutes and then recovered for 6 hours. mRNA sequencing was performed to compare changes in gene expression between the striatums of sham control and deep hypothermic circulatory arrest brains.

Results: We found 124 significantly upregulated genes and 74 significantly downregulated genes in the striatums of the deep hypothermic circulatory arrest group compared with the sham controls. Pathway enrichment analysis demonstrated that inflammation and apoptosis were the strongest pathways activated after surgery. Chemokines CXCL9, CXCL10, and CCL2 were the top upregulated genes with 32.4-fold, 22.2-fold, and 17.6-fold increased expression, respectively, in the deep hypothermic circulatory arrest group compared with sham controls. Concomitantly, genes involved in cell proliferation, cell-cell adhesion, and structural integrity were significantly downregulated in the deep hypothermic circulatory arrest group. Analysis of promoter regions of all upregulated genes revealed over-representation of nuclear factor-kB transcription factor binding sites.

Conclusions: Our study provides a comprehensive view of global transcriptional changes in the striatum after deep hypothermic circulatory arrest and found strong activation of both inflammatory and apoptotic signaling pathways in the deep hypothermic circulatory arrest group. Nuclear factor-kB, a key driver of inflammation, appears to be an upstream regulator of the majority of the upregulated genes; hence, nuclear factor-kB inhibitors could potentially be tested for beneficial effects on neurologic outcome. (J Thorac Cardiovasc Surg 2019;158:882-90)

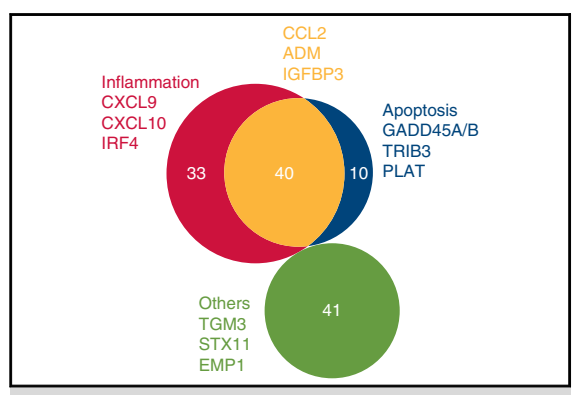

Significantly upregulated genes in the striatum after DHCA.

\section{Central Message}

Our study provides a comprehensive view of transcriptional changes in the striatum after deep hypothermic cardiac arrest and found strong activation of both inflammatory and apoptotic pathways.

\section{Perspective}

Brain injury is a major complication in neonates undergoing cardiac surgeries. mRNA sequencing identified strong activation of both inflammatory and apoptotic signaling pathways in the striatum after $\mathrm{CPB}$ and associated DHCA. NF-kB, a key driver of inflammation, appears to be an upstream regulator of the majority of the upregulated genes; hence, NF-kB inhibitors could potentially be tested for beneficial effects on neurologic outcome.

See Commentaries on pages 891 and 893.
Congenital heart disease is one of the most common birth defects necessitating early surgical intervention. As survival increases, the focus has now been shifted to improve

\footnotetext{
From the ${ }^{\mathrm{a} D e p a r t m e n t}$ of Pediatrics (Cardiology), University of Washington, Seattle Wash; ${ }^{b}$ Center for Developmental Biology and Regenerative Medicine, Seattle Children's Research Institute, Seattle, Wash; ${ }^{\mathrm{c}}$ Ward Family Heart Center, Children's Mercy Hospital, Kansas City, Mo; ${ }^{\text {d}}$ College of Biosciences, Kansas City University of Medicine and Biosciences, Kansas City, Mo; ${ }^{\mathrm{e}}$ Department of Biochemistry and Biophysics, University of Pennsylvania, Philadelphia, Pa; and ${ }^{\mathrm{f}}$ Department of Cardiovascular Surgery, Icahn School of Medicine at Mount Sinai, New York, NY.

Funded by the Ward Family Heart Center at Children's Mercy.

Received for publication Oct 16, 2018; revisions received Feb 8, 2019; accepted for publication Feb 22, 2019; available ahead of print April 17, 2019.
}

long-term outcomes, particularly neurodevelopmental ones. Long-term follow-up studies have shown that school-age survivors of newborn or infant cardiac bypass surgery have

\footnotetext{
Address for reprints: Peter Pastuszko, MD, Department of Cardiovascular Surgery, Icahn School of Medicine at Mount Sinai, 1184 5th Ave, Box 1028, New York, NY 10029-6574 (E-mail: peter.pastuszko@mountsinai.org); and Vishal Nigam, MD, Department of Pediatrics (Cardiology), University of Washington, 1900 9th Ave, Seattle, WA 98101 0022-5223/\$36.00

Copyright (C) 2019 Published by Elsevier Inc. on behalf of The American Association for Thoracic Surgery

https://doi.org/10.1016/j.jtcvs.2019.02.091
} 

Abbreviations and Acronyms
$\mathrm{CPB}=$ cardiopulmonary bypass
$\mathrm{CSF}=$ cerebrospinal fluid
DHCA $=$ deep hypothermic circulatory arrest
$\mathrm{NF}-\mathrm{kB}=$ nuclear factor kappa-light-chain-enhancer of activated B cells
$\mathrm{TF}=$ transcription factor

Scanning this QR code will

take you to the article title page to access supplementary information.

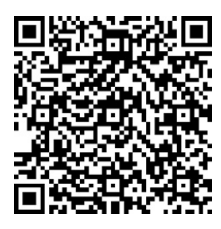

a high prevalence of cognitive impairment, attention-deficit hyperactivity disorder, and impaired visual-motor skills. ${ }^{1,2}$ The etiology for this neurodevelopmental sequelae is multifactorial, comprising of both patient factors such as congenital syndromes and genetic abnormalities, as well as procedure-related factors. ${ }^{1-3}$ Because patient factors are not readily modifiable, deeper understanding about the etiology of brain injuries caused by the procedure itself would help improve neurologic outcomes.

Most neonatal cardiac surgeries use cardiopulmonary bypass (CPB) pump to maintain organ perfusion. In certain complex surgeries, deep hypothermic circulatory arrest (DHCA) is used, in which complete cessation of circulation is accompanied with profound systemic hypothermia at $18^{\circ} \mathrm{C}$ to $20^{\circ} \mathrm{C}$ to preserve vulnerable organs such as the brain. Despite the efforts to minimize organ damages, it has been documented that hypoxic-ischemic insult followed by reperfusion insult can have detrimental effects. ${ }^{4}$ Hypoxicischemic insult is believed to be the leading cause of postoperative neuronal death that subsequently results in long-term neurologic disability. Microemboli, coolingrewarming, hemodilution and exposure to blood products, artificial surface, and chemicals are other CPB-associated insults that could play a role in the pathogenesis of neuronal dysfunction after cardiac surgery. ${ }^{4}$

By using piglet models of CPB and DHCA, we and others have demonstrated that the mechanism of neuronal death is primarily by apoptosis, which occurs as early as a few hours in reperfusion and continues for several days. ${ }^{5-7}$ However, further mechanistic insights into cellular pathways driving apoptosis or other substantial changes besides apoptosis remain limited. Current strategies for neuroprotection include prevention of injuries by improving anesthetic and surgical techniques, or promotion of growth at recovery phase using erythropoietin and neurotrophic factors. ${ }^{3,4}$ These approaches have not eliminated the damage to the brain. To strategically develop new neuroprotective agents to block early signaling cascades that lead to the damage, we need to first understand the early molecular changes in the brain.

In this study, we subjected newborn piglets to 2 hours of $\mathrm{CPB}$ with DHCA for 30 minutes at $18^{\circ} \mathrm{C}$, followed by recovery for 6 hours. We focused on the striatum because striatum is critically involved in decision-making, reward cognition, control, and refinement of motor functions. Our previous studies also showed that striatum is one of the most vulnerable regions in the brain. ${ }^{6,8}$ Therefore, we performed whole transcriptome sequencing to unbiasedly delineate all transcriptional changes in the striatum after CPB and associated circulatory arrest. We also aimed to identify upstream transcription factors (TFs), which are proteins that turn specific genes "on" and "off" by binding to their promoter sequences. This helps us gain understandings of how transcriptional response to DHCA is regulated at the genomic level.

\section{MATERIALS AND METHODS}

\section{Animal Model}

Experiments were conducted as described previously. ${ }^{6,8}$ Briefly, 12 newborn piglets from multiple litters were obtained from Meck Swine, LLC (Refton, Pa) at 3 to 5 days old. The piglets were anaesthetized with $4 \%$ isoflurane and then intubated and mechanically ventilated. Animals were maintained with $1.5 \%$ isoflurane supplemented with fentanyl citrate ( $30 \mu \mathrm{g} / \mathrm{kg}$ bolus) as needed. Pancuronium bromide $(0.1 \mathrm{mg} / \mathrm{kg}$ bolus repeated, as needed) was used to induce neuromuscular blockade.

For the CPB procedure, median sternotomy was performed, and the ascending aorta and the right atrial appendage were cannulated. The cardiopulmonary circuit was primed with whole blood obtained from a donor pig; a dose of steroid was added to the circuit during priming. CPB flow rate was maintained at approximately $150 \mathrm{~mL} / \mathrm{kg} / \mathrm{min}$. The piglets were then cooled over a 20 - to 30 -minute period by $\mathrm{pH}$-stat blood gas management to a nasopharyngeal/brain temperature of $18^{\circ} \mathrm{C}$. The temperature-corrected arterial blood $\mathrm{pH}$ was maintained at 7.4 by the addition of $\mathrm{CO}_{2}$. Once the target temperature was achieved, the piglets were subjected to 30 minutes of DHCA. CPB was then resumed at $150 \mathrm{~mL} / \mathrm{kg} / \mathrm{min}$, and the piglets were rewarmed to $37^{\circ} \mathrm{C} \pm 1^{\circ} \mathrm{C}$ for a 30 -minute period. $\mathrm{CPB}$ was discontinued when body temperature reached $37^{\circ} \mathrm{C}$ and ventilation was reinitiated 5 minutes before weaning from CPB. All animals received analgesia, paralysis, and mechanical ventilation, and were continuously monitored throughout the recovery period of 6 hours after weaning from CPB. No inotropes were used, and the post-CPB arterial blood pressure was maintained with an infusion of saline/packed red blood cells to keep mean arterial blood pressure above $50 \mathrm{~mm} \mathrm{Hg}$. The hematocrit of the animals was maintained at $25 \%$ to $30 \%$ throughout the duration of bypass and recovery. At the end of each experiment, piglets were first perfused with heparinized saline and the striatum was extracted and frozen immediately for RNA extraction.

All animal procedures were carried out in accordance with the National Institutes of Health Guide for the Care and Use of Laboratory Animals and were approved by the Institutional Animal Care and Use Committee of the University of Pennsylvania.

\section{Whole Transcriptome Shotgun Sequencing}

Total RNA from the striatum was extracted using the MirVana RNA extraction kit (Invitrogen, Carlsbad, Calif). The concentration and quality of total RNA for each sample were quantified and evaluated by spectrophotometric (Epoch; Thermo Scientific, Waltham, Mass) and automated chip electrophoresis analyses (Experion, BioRad, Hercules, 

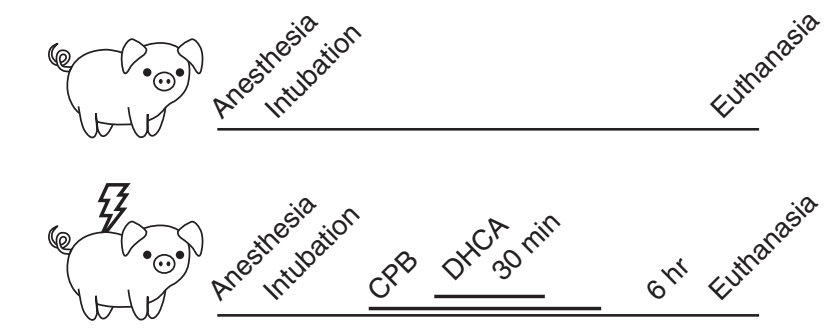

A

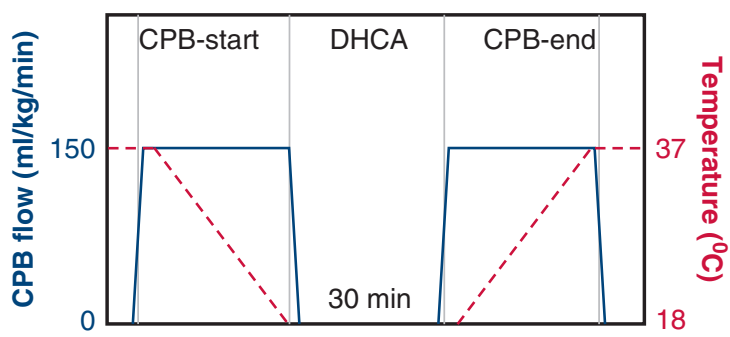

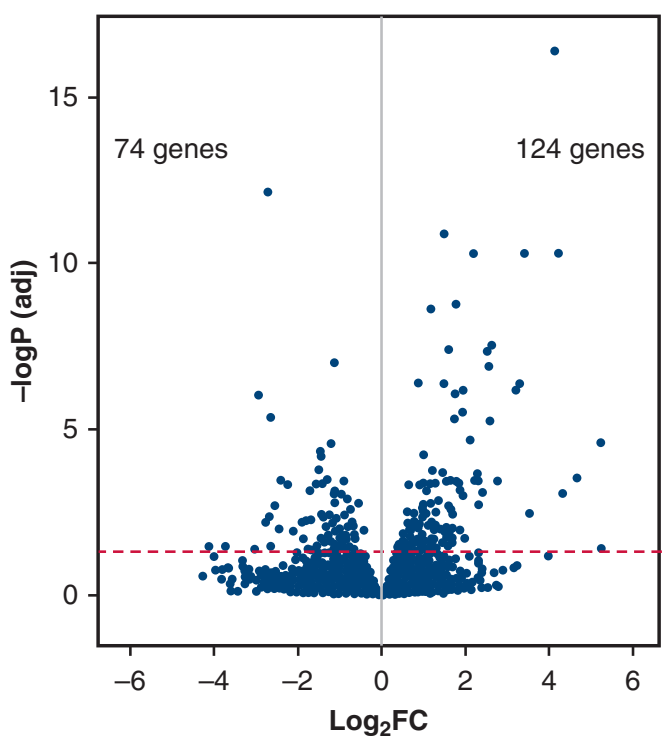

C

FIGURE 1. Diagrams of experimental procedure and whole transcriptome sequencing result. A, All piglets were anaesthetized, mechanically ventilated, and monitored throughout the procedure. CPB was initiated in the experimental group, followed by 30 minutes of DHCA. Six hours after weaning from $\mathrm{CPB}$, animals were euthanized and striatum was dissected for transcriptome sequencing. B, The plot showed details of flow rate and temperature changes during the procedure. CPB flow rate was first maintained at $150 \mathrm{~mL} / \mathrm{kg} / \mathrm{min}$. Piglets were then cooled over 20 to 30 minutes to reach a brain temperature of $18^{\circ} \mathrm{C}$. Once the target temperature was achieved, piglets were subjected to 30 minutes of DHCA. CPB was then resumed at $150 \mathrm{~mL} / \mathrm{kg} / \mathrm{min}$, and the piglets were rewarmed to $37^{\circ} \mathrm{C}$ for 30 minutes. When body temperature reached $37^{\circ} \mathrm{C}, \mathrm{CPB}$ was discontinued. $\mathrm{C}$, Volcano plot shows fold changes and $P$ values of all transcripts detected in the striatum after DHCA. Genes with adjusted $P<.05$ (above red line) were included in further analysis. In total, there were 74 sigificantly downregulated genes and 124 significantly upregulated genes. $C P B$, Cardiopulmonary bypass; $D H C A$, deep hypothermic circulatory arrest.

Calif), respectively. Each sample met our quality standards of a 260/280 ratio greater than 2.0 and a RNA integrity number greater than 9 . Illumina TruSeq RNA Sample Preparation Kit was used to generate cDNA libraries from $1 \mu \mathrm{g}$ total RNA and sequenced on a HiSeq 1500 platform (Illumina, San Diego, Calif) by the Children's Mercy OMICS Research Core Lab, Kansas City, Missouri.

\section{Statistical Analysis}

RNA sequence reads were aligned to the Pig genome (Sscrofa11.1) using Star. ${ }^{9}$ Aligned reads mapping to the exons of a gene were assigned using featureCounts. ${ }^{10}$ DESeq $2^{11}$ was used to normalize the data using regularized-logarithm to examine the relationship between samples and to test for differential expression. Sample relationships were observed by plotting the first 2 principal components. DESeq2 uses the Wald test for determining if a gene is significantly differentially expressed, and $P$ values were adjusted for multiple testing using Benjamini-Hochberg adjustment. These data have been deposited at GEO (GSE120863).

Differentially expressed genes were classified by gene ontology terms using Protein Analysis Through Evolutionary Relationships tool at Pantherdb.org. Pathway enrichment analysis was performed using gene annotation and analysis resource Metascape at metascape.org. Conserved $\mathrm{TF}$ binding sites that are over-represented in the gene list were analyzed using oPOSSUM at opossum.cisreg.ca. Each TF was assigned a Fisher score that determines the probability of a nonrandom association between the gene set and the TF of interest, and a $z$-score that measures frequency of occurrence of a TF binding site in the gene set compared with a background set in the oPOSSUM database.

\section{RESULTS}

In this study, newborn piglets were subjected to DHCA at $18^{\circ} \mathrm{C}$ for 30 minutes, followed by rewarming and full flow of CPB at $150 \mathrm{~mL} / \mathrm{kg} / \mathrm{min}$; total CPB support was 2 hours (Figure 1, $A$ and $B$ ). After 6 hours of recovery, striata were harvested for whole transcriptome sequencing to compare changes in gene expression between sham and experimental groups ( $\mathrm{n}=6$ animals/group). Of 21,036 transcripts detected by sequencing, 15,740 transcripts were successfully mapped to the annotated swine genome. A total of 124 genes were found significantly upregulated (adjusted $P<.05$ ) and 74 genes were significantly downregulated (adjusted $P<.05$ ) in the DHCA group compared with the sham controls (Figure 1,C).

We first used Protein Analysis Through Evolutionary Relationships tool (PANTHER) to classify significantly upregulated genes by the molecular functions they perform on their direct targets and by the cellular component, which is the location where they perform their functions. A large proportion of the genes have binding $(43 \%)$ or catalytic activities $(36 \%)$ (Figure 2, A). Main locations are cell parts $(40.7 \%)$ that include cytoplasm and plasma membrane, and cellular organelles $(25 \%)$, comprising mainly the nucleus (Figure 2, B). Pathway enrichment analysis was then performed using Metascape to identify biological processes that were significantly altered after DHCA exposure. We found strong enrichments in inflammatory response pathways with 73 genes classified as involved in cytokine and chemokine signaling (Figure 3). In particular, the chemokines $\mathrm{C}-\mathrm{X}-\mathrm{C}$ motif chemokine ligand 9 

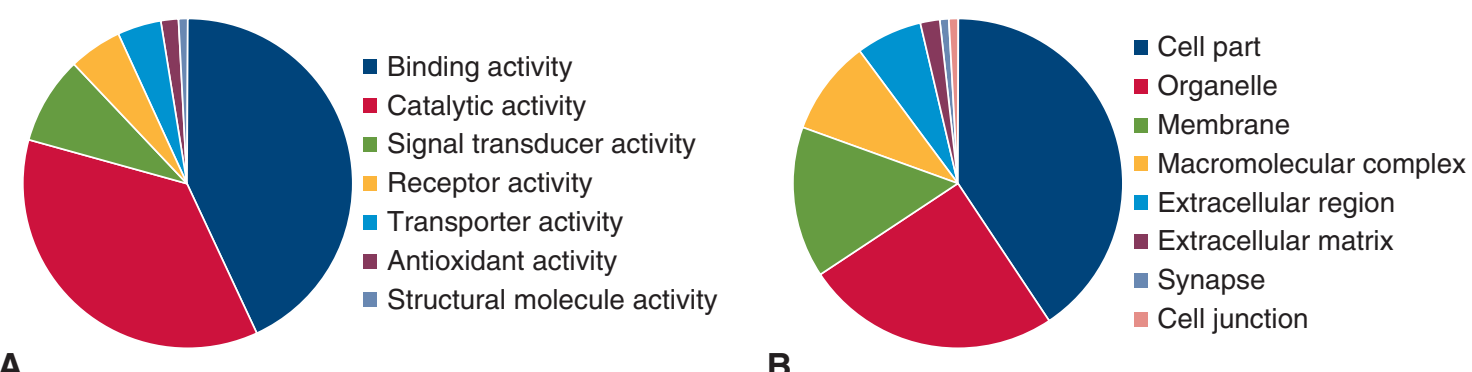

FIGURE 2. Distribution of gene ontology terms for significantly upregulated genes in the striatum after DHCA using Protein Analysis Through Evolutionary Relationships tool. A, Distributions of gene ontology term describing molecular functions of all significantly upregulated transcripts. Forty-three percent of the genes have binding activity, and $36 \%$ of the genes have catalytic activity. B, Distributions of gene ontology term describing cellular components of all significantly upregulated transcripts. Cellular component is the location where a gene performs its function. The majority of the upregulated genes are located in the cell parts $(40.7 \%)$ that include cytoplasm, plasma membrane, and cellular organelles (25\%), comprising mainly the nucleus.

(CXCL9), C-X-C motif chemokine ligand 10 (CXCL10), and $\mathrm{C}-\mathrm{C}$ motif chemokine ligand 2 (CCL2) were the top 3 upregulated genes with 32.4-, 22.2-, and 17.6-fold increases, respectively, after DHCA exposure compared with sham controls (Table 1). Interferon regulator factor 4 (IRF4) (up 15.6-fold), one of the top 3 genes specifically involved in inflammation (Figure 3, $B$ ), is a TF that activates microglia/macrophages and modulates proinflammatory responses. In addition, apoptotic signaling is the secondmost enriched pathway with 50 genes upregulated in the DHCA group (Figure 3). Oxidative stress induced growth inhibitor 1-OSGIN1 (up 3.7-fold) and Ras-related protein RAB20 (up 3.3-fold) are key activators of apoptosis in response to oxidative stress and hypoxia, respectively ${ }^{12-16}$ (Table 1). Among genes specifically involved in apoptosis (Figure 3, $B$ ), growth arrest and DNA damage-inducible $\alpha$ and $\beta$ GADD45A/B were the most upregulated with 3.2fold increase after DHCA (Table 1). Tribble homolog 3 (TRIB3) (up 2.9-fold, Table E1) could sensitize cells to apoptosis and negatively regulate AKT $1,{ }^{17}$ which is a cell survival serine/threonine kinase. Tissue plasminogen activator (PLAT) (up 2.9-fold, Table E1), a key player in thrombolysis, has been demonstrated to promote cell death. ${ }^{18}$ Of note, there was significant overlap between inflammatory and apoptotic responses because up to 40 genes were classified as involved in both inflammatory and apoptotic
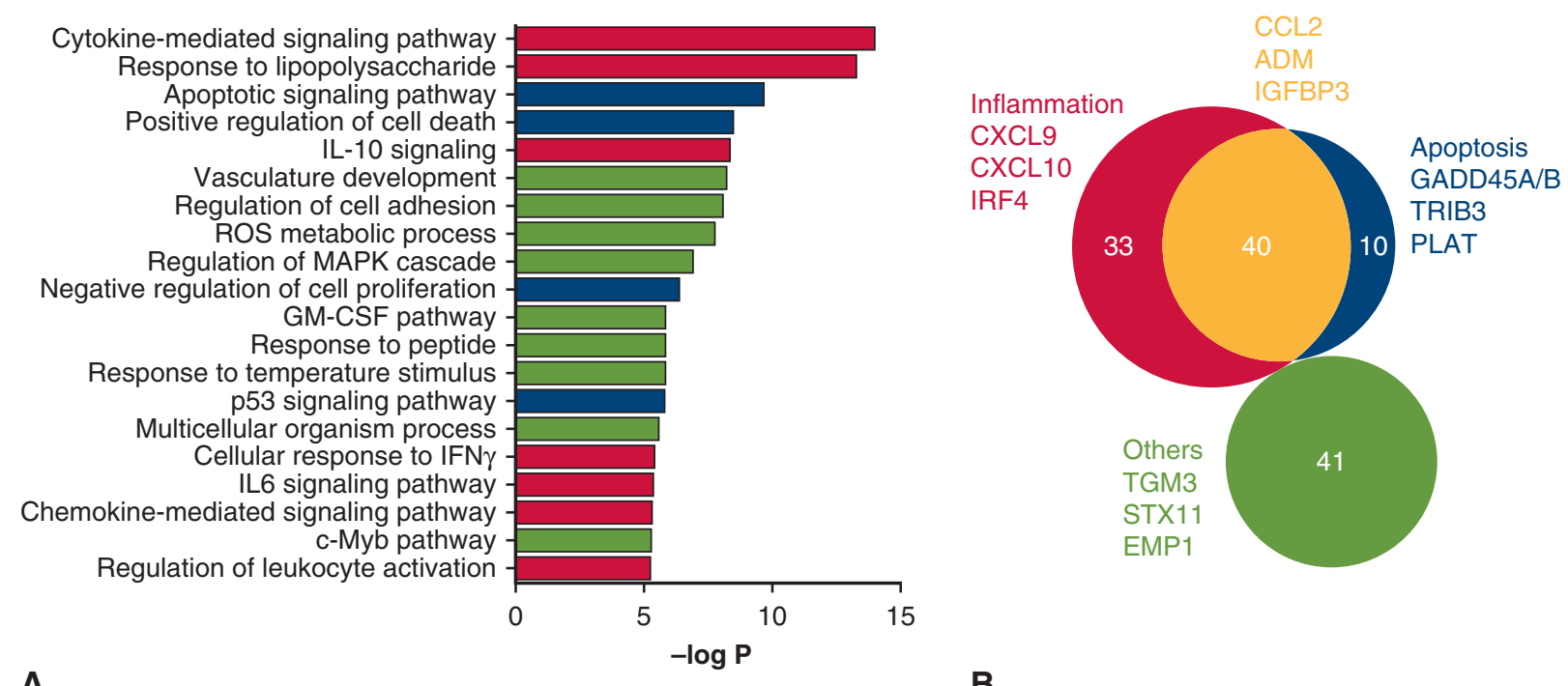

A

\section{B}

FIGURE 3. Pathway enrichment analysis for significantly upregulated genes in the striatum after DHCA using Metascape. A, Top significantly enriched pathways were inflammatory signaling pathways (in red) and cellular apoptotic pathways (in blue). B, Distribution of genes in different groups of pathways. A total of 33 genes (in red) were specifically involved in inflammatory pathways and the top 3 upregulated genes were CXCL9, CXCL10, and CCL2. A total of 10 genes (in blue) were specifically involved in apoptosis, and the top 3 upregulated genes were GADD45A/B, TRIB3, and PLAT. A total of 40 genes were classified as commonly involved in both inflammation and apoptosis, and the top 3 upregulated genes were CCL2, ADM, and IGFBP3. A total of 41 genes (in green) were classified as involved in other pathways, and the top 3 upregulated genes were TGM3, STX11, and EMP1. IL, interleukin; ROS, reactive oxygen species; GM-CSF, Granulocyte-macrophage colony-stimulating factor; $I F N$, interferon. 
TABLE 1. List of genes that were significantly upregulated at least 3-fold in the striatum

\begin{tabular}{|c|c|c|c|}
\hline ID & Name & FC & Adjusted $P$ value \\
\hline CXCL9 & C-X-C motif chemokine ligand 9 & 32.4 & .042 \\
\hline CXCL10 & $\mathrm{C}-\mathrm{X}-\mathrm{C}$ motif chemokine ligand 10 & 22.2 & $<.001$ \\
\hline CCL2 & C-C motif chemokine ligand 2 & 17.6 & .001 \\
\hline TGM3 & Transglutaminase 3 & 16.4 & $<.001$ \\
\hline IRF4 & Interferon regulatory factor 4 & 15.6 & $<.001$ \\
\hline $\mathrm{ADM}$ & Adrenomedullin & 9.6 & $<.001$ \\
\hline MT1A & Metallothionein 1A & 8.5 & $<.001$ \\
\hline STX11 & Syntaxin 11 & 6.3 & $<.001$ \\
\hline IGFBP3 & Insulin like growth factor binding protein 3 & 5.8 & $<.001$ \\
\hline THBS1 & Thrombospondin 1 & 5.6 & $<.001$ \\
\hline SERPINE1 & Serpin family E member 1 & 5.5 & $<.001$ \\
\hline EMP1 & Epithelial membrane protein 1 & 5.4 & $<.001$ \\
\hline BATF2 & Basic leucine zipper ATF-like transcription factor 2 & 5.0 & .001 \\
\hline $\mathrm{CD} 274$ & CD274 molecule & 4.7 & .002 \\
\hline FAM111A & Family with sequence similarity 111 member A & 4.6 & $<.001$ \\
\hline GEM & GTP binding protein overexpressed in skeletal muscle & 4.4 & $<.001$ \\
\hline SLA & Src like adaptor & 4.3 & $<.001$ \\
\hline CEBPD & CCAAT enhancer binding protein delta & 4.1 & $<.001$ \\
\hline OSGIN1 & Oxidative stress induced growth inhibitor 1 & 3.7 & .001 \\
\hline FKBP5 & FK506 binding protein 5 & 3.7 & $<.001$ \\
\hline LRRC32 & Leucine rich repeat containing 32 & 3.7 & $<.001$ \\
\hline PTGS2 & Prostaglandin-endoperoxide synthase 2 & 3.5 & .001 \\
\hline TIFA & TRAF interacting protein with forkhead associated domain & 3.5 & .001 \\
\hline SRGN & Serglycin & 3.4 & $<.001$ \\
\hline RAB20 & RAB20, member RAS oncogene family & 3.3 & $<.001$ \\
\hline TLR2 & Toll like receptor 2 & 3.3 & $<.001$ \\
\hline HAVCR2 & Hepatitis A virus cellular receptor 2 & 3.2 & $<.001$ \\
\hline GADD45A & Growth arrest and DNA damage inducible alpha & 3.2 & $<.001$ \\
\hline MAFF & MAF bZIP transcription factor $F$ & 3.1 & .026 \\
\hline RTL9 & Retrotransposon Gag like 9 & 3.1 & .004 \\
\hline GADD45B & Growth arrest and DNA damage inducible beta & 3.1 & .018 \\
\hline ICAM1 & Intercellular adhesion molecule 1 & 3.1 & .009 \\
\hline SLC7A2 & Solute carrier family 7 member 2 & 3.1 & $<.001$ \\
\hline OSMR & Oncostatin M receptor & 3.1 & .003 \\
\hline
\end{tabular}

signaling pathways (Figure $3, B$ ). Insulin like growth factor binding protein 3 (IGFBP3) (up 5.8-fold) and CCAAT/ enhancer-binding protein delta (CEBPD) (up 4.9-fold) were previously shown as common regulators of both inflammatory and apoptotic processes. ${ }^{19,20}$ Adrenomedullin (ADM) (up 9.6-fold) is a vasodilator hormone with unclear significance in brain physiology. Together, these results indicate that both inflammation and apoptosis were strongly activated in the striatum early postsurgery. Several other pathways were also significantly altered in the DHCA group (Figure 3,A) with 41 genes being upregulated (Figure 3, B). The top 3 genes were transglutaminase 3 (TGM3) (up 16.4-fold), syntaxin 11 (STX11) (up 6.3-fold), and epithelial membrane protein 1 (EMP1) (up 5.4-fold).

The significantly downregulated genes have diverse molecular functions and were not enriched in relevant pathways. However, we noticed that several genes critically involved in promoting cell growth and proliferation were severely downregulated after DHCA, such as Forkhead box genes FOXQ1 (down 5.7-fold) and FOXF2 (down 4.0-fold), and growth factors: Epidermal growth factor (EGF) (down 2.4-fold) and fibroblast growth factor 11 (FGF11) (down 1.7-fold) (Tables 2 and E2). This result 
TABLE 2. List of genes that were significantly downregulated at least 3-fold in the striatum

\begin{tabular}{|c|c|c|c|}
\hline ID & Name & FC & Adjusted $P$ value \\
\hline TTR & Transthyretin & 7.4 & .042 \\
\hline ALS2CL & ALS2 C-terminal like & 6.9 & $<.001$ \\
\hline FCRL1 & Fc receptor like 1 & 6.1 & .006 \\
\hline SLC52A3 & Solute carrier family 52 member 3 & 5.9 & $<.001$ \\
\hline ARHGEF15 & Rho guanine nucleotide exchange factor 15 & 5.8 & .005 \\
\hline PCDH12 & Protocadherin 12 & 5.7 & $<.001$ \\
\hline FOXQ1 & Forkhead box Q1 & 5.7 & .034 \\
\hline CA4 & Carbonic anhydrase 4 & 5.3 & .002 \\
\hline PRDM8 & PR/SET domain 8 & 5.0 & .010 \\
\hline SLC19A3 & Solute carrier family 19 member 3 & 4.9 & $<.001$ \\
\hline USHBP1 & Usher syndrome $1 \mathrm{C}$ binding protein 1 & 4.3 & .001 \\
\hline FOXF2 & Forkhead box F2 & 4.0 & .012 \\
\hline KRT23 & Keratin 23 & 3.4 & .006 \\
\hline ZIC5 & Zic family member 5 & 3.4 & .020 \\
\hline PGGHG & Protein-glucosylgalactosylhydroxylysine glucosidase & 3.2 & .006 \\
\hline ADAMTS16 & ADAM metallopeptidase with thrombospondin type 1 motif 16 & 3.2 & .042 \\
\hline FBXL13 & F-box and leucine rich repeat protein 13 & 3.1 & .042 \\
\hline HBB & Hemoglobin subunit beta & 3.1 & .001 \\
\hline VWA2 & Von Willebrand factor A domain containing 2 & 3.0 & .042 \\
\hline MEGF6 & Multiple EGF like domains 6 & 3.0 & .005 \\
\hline
\end{tabular}

further supports our observation of increased apoptosis in the striatum after DHCA. Moreover, there was noticeable decline in cell-cell adhesion and structural integrity, characterized by reduced expressions of protocadherin genes PCDH12 (down 5.7-fold) and PCDH18 (down 1.9-fold); laminin subunit $\alpha 1$ (LAMA1) (down 1.6-fold); and intermediate filaments keratin 23 (KRT23) (down 3.4-fold) and nestin (NES) (down 2.5-fold) (Tables 2 and E2). Carbonic anhydrase 4 (CA4), the enzyme responsible for maintaining acid-base balance in tissues, was downregulated by 5.3-fold, indicating significant acid-base disturbance due to exposure to hypoxicischemic condition during DHCA-CPB. Last, the most significantly downregulated gene, transthyretin (TTR) (down 7.4-fold), has the main function of transporting thyroxine and retinol in cerebrospinal fluid (CSF) and is strongly associated with amyloidosis and proteotoxicity. Its level has been found to be low in several neurologic disorders, but the function and relevance in this context are unclear.

To identify upstream TF that might play a role in activating the observed transcriptional response to DHCA, we searched for enrichment of TF binding sites in the 10-kb sequence upstream and downstream of transcription start sites of all 124 significantly upregulated genes. We found striking over-representation of binding sites for RELA (NF-kB p65) $\left(P=8.38 \mathrm{E}^{-14}\right)$, nuclear factor kappa-light-chain-enhancer of activated B cells - NF-kB
$\left(P=2.92 \mathrm{E}^{-12}\right)$, and $\mathrm{c}-\mathrm{REL}\left(P=3.84 \mathrm{E}^{-11}\right)$, which all belong to the NF-kB family, as well as signal transducer and activator of transcription 1 (STAT1) $\left(P=6.17 \mathrm{E}^{-10}\right)$ and nuclear factor of activated $\mathrm{T}$ cells 2 (NFATC2) $\left(P=2.00 \mathrm{E}^{-06}\right)$ (Figure 4, A). Of note, we found that a large number of genes have putative binding sites for multiple TFs in their promoters. For instance, 44 genes have binding sites for all NF-kB TFs, STAT1, and NFATC2 (in dark blue) (Figure $4, B$ ); only 3 genes have exclusive binding site for NF-kB TFs (in yellow), and only 26 genes are specifically regulated by NFATC2 (in light blue) (Figure $4, B$ ). Furthermore, NF-kB target genes accounted for $63 \%$ of all the significantly upregulated genes in the DHCA-exposed striatum (Figure 4, $C$ ). In different pathway subsets, NF-kB target genes accounted for $64 \%, 68 \%$, and $51 \%$ of genes involved in inflammation, apoptosis, and other pathways, respectively. This strongly indicates that activation of NF-kB pathway could be upstream signaling responsible for the inflammatory and apoptotic responses in the striatum after DHCA-CPB surgery.

\section{DISCUSSION}

Neurologic complications of cardiac surgery in neonates and infants have long been documented, with the prevalent theory that neuronal apoptotic death due to hypoxic-ischemic injury is the leading cause. ${ }^{1-3,5}$ However, there has not been a systematic and unbiased investigation to elucidate all cellular pathways being 

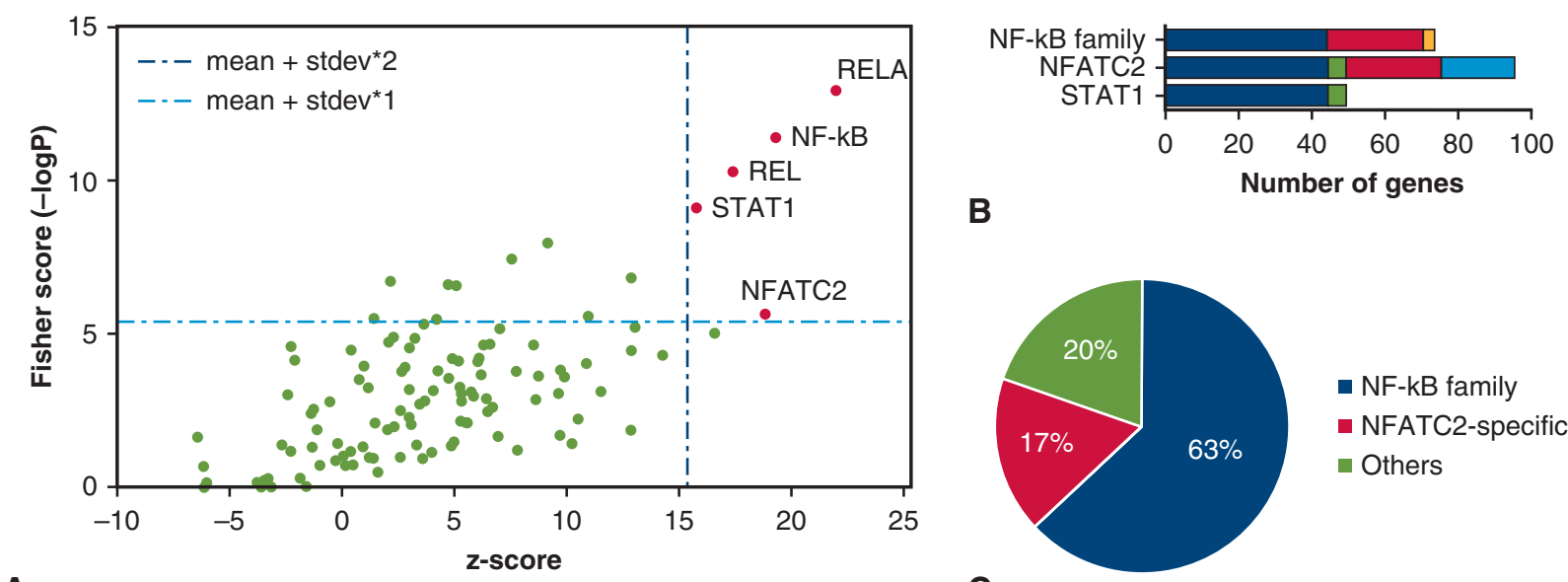

B

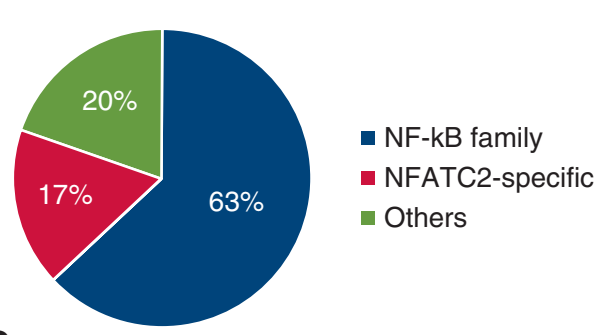

C
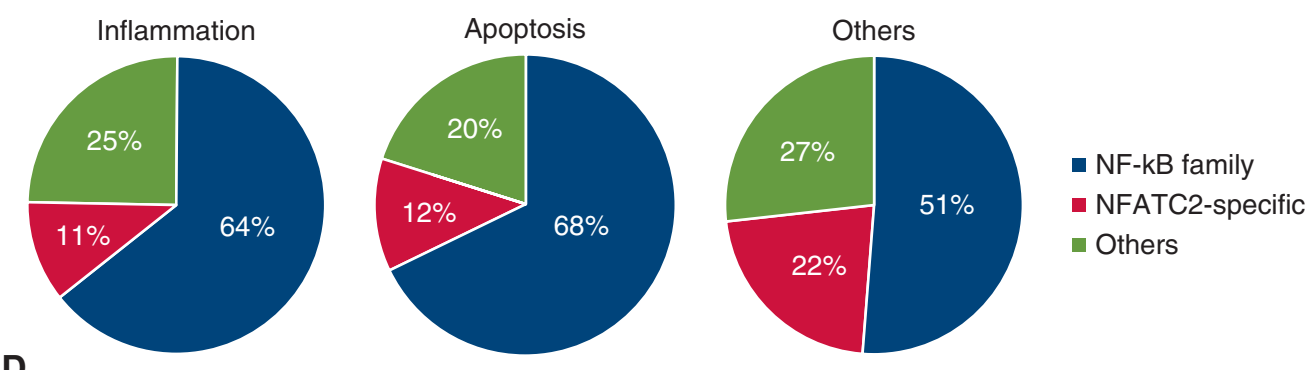

FIGURE 4. Identification of TFs regulating upregulated genes in the striatum after DHCA using oPOSSUM. A, TFs whose binding sites were enriched in the promoters of significantly upregulated genes were identified and are highlighted in red. The Fisher exact probability test (x axis) determines the probability of a nonrandom association between the gene set and the TF of interest. The $z$-score (y axis) measures frequency of occurrence of a TF binding site in the gene set compared with a background set in the oPOSSUM database. We found over-representation of binding sites for RELA, NF-kB, and c-REL, which all belong to the NF-kB family, as well as STAT1 and NFATC2. B, The graph showed the number of genes that have binding sites for NF-kB TF family, NFATC2, and other TFs in their promoter regions. Several genes had putative binding sites for multiple TFs. C, The pie chart showed proportions of all upregulated genes that have binding sites for NF-kB TF family, NFATC2-specific, and other TFs. NF-kB target genes accounted for $63 \%$ of all the significantly upregulated genes. D, The pie chart shows proportions of genes involved in inflammation, apoptosis, and other pathways that have binding sites for NF-kB TF family, NFATC2, and other TFs. NF-kB target genes accounted for $64 \%, 68 \%$, and $51 \%$ of genes involved in inflammation, apoptosis, and other pathways, respectively. $N F-k B$, Nuclear factor kappa-light-chain-enhancer of activated B cells.

altered in the brain after surgery. Therefore, using a piglet model and whole genome transcriptome sequencing, our study provided a comprehensive view of all transcriptional changes in the striatum after DHCA-CPB.

Piglets were used to leverage the similar stage of brain development and the similar size to human neonates. Newborn piglets were subjected to 2 hours of CPB with DHCA at $18^{\circ} \mathrm{C}$ for 30 minutes, which is representative of standard protocol adopted by surgeons in clinical practice for complex cardiac surgeries. Striatum was harvested 6 hours after recovery, which is an early postoperative time point when we expect to capture significant transcriptional changes that could drive later pathological outcomes.

We and other groups have demonstrated that neuronal death is prominent in striatum after surgery primarily by apoptosis, as characterized by increased TUNEL-positive cells, elevated caspase- 3 and 8 activities, and translocation of cytochrome $\mathrm{c}$ from mitochondria to cytosol. ${ }^{5-8}$ Our results not only further corroborate that apoptosis is strongly upregulated in the striatum early after DHCA-CPB but also provide further insights into mechanisms leading to apoptosis. RAB20, a direct transcriptional target of hypoxia-inducible factor $\mathrm{HIF} 1 \mathrm{a},{ }^{12,13}$ was upregulated by 3.3 -fold, clearly indicating the presence of hypoxic injury in the striatum. RAB20 has physiologic functions in intracellular trafficking ${ }^{12,13}$ but localizes to mitochondria to induce apoptosis in response to hypoxia ${ }^{13}$ and inhibits neurite growth. ${ }^{21}$ OSGIN1, upregulated by 3.7-fold, is a key activator of apoptosis in response to oxidative stress, ${ }^{14-16}$ very likely due to ischemiareperfusion injury. OSGIN1 is activated by $\mathrm{p} 53$ and has been shown to translocate to mitochondria and responsible for inducing release of cytochrome $\mathrm{c}$ to cytosol. ${ }^{15,16} \mathrm{It}$ has been proposed that postoperative mitochondrial dysfunction also plays a role in triggering cytochrome $\mathrm{c}$ release. ${ }^{22}$ However, we found no significant changes in expression of mitochondrial metabolic genes, except for 
significant downregulation of mitochondrial fatty acid oxidation gene CPT1b by 2.1-fold (Table E2).

Systemic inflammation during cardiac surgery has been recognized for years as evidenced by increased levels of serum cytokines interleukin- $1 \beta, 6$, and 8 in neonatal patients after surgery. ${ }^{23,24}$ The damaging effect of such systemic response on the brain is presumed but yet to be clearly demonstrated, because correlation between serum cytokine level and neurologic outcome remains controversial. ${ }^{25}$ One widely accepted mechanism is that systemic inflammatory cytokines could disrupt the blood-brain barrier, ${ }^{26}$ alter neurotransmission, and thus release cerebral specific proteins into CSF and blood circulation. This has been demonstrated by increased levels of some biomarkers for brain damage such as neuron-specific enolase and s100B in sera of neonatal patients after cardiac surgery. ${ }^{27}$ Evidence for local inflammation in the brain and CSF is not yet available from patients, but only in animal models of bypass. Proinflammatory cytokines interleukin- $1 \beta$ and 6 , and tumor necrosis factor- $\alpha$ were found significantly elevated in different brain regions after bypass surgery in rats. ${ }^{28,29}$ With the use of a piglet model of DHCA, our study provided a holistic map of all transcriptional changes and concluded that inflammatory signaling was not only present but also the strongest response in the striatum after DHCA-CPB. Inflammation might have arisen concurrently with apoptosis or more likely contributed to drive apoptosis per se because we found significant overlap between the genes involved in these 2 processes. Indeed, one of the top upregulated chemokines CXCL10 has been shown to induce apoptosis in neurons. ${ }^{30}$ In addition, we speculate that early upregulation of chemokines CXCL9, CXCL10, and CCL2 could play a key role in recruitment and activation of infiltrating immune cells, resulting in further brain damage at a later postoperative stage. Furthermore, these chemokines might be potential biomarkers for inflammation and injury in the striatum and the whole brain. CXCL9 and CXCL10 have been demonstrated as reliable CSF chemokine markers for multiple sclerosis. ${ }^{31}$ This application would be helpful in postoperative management.

We found that NF-kB binding sites were prominently enriched in promoters of $63 \%$ upregulated genes, suggesting a crucial role of NF-kB signaling in mediating the majority of transcriptional response to DHCA. Indeed, several top upregulated genes in our data have been shown as direct targets of NF-kB such as IRF4, ${ }^{32}$ GADD45B, ${ }^{33}$ and CEBPD. ${ }^{34} \mathrm{NF}-\mathrm{kB}$ is a powerful TF that controls expression of various cytokines, chemokines, and cell survival proteins in response to stress stimuli. NF-kB expression has been found upregulated in the brain of several animal models for bypass but often detected at a much later postoperative timepoint. ${ }^{28,29}$ Here we speculate that expression of
NF-kB could be elevated early and responsible for activating various genes in inflammatory and apoptotic cascades. Therefore, pharmacologically blocking NF-kB signaling might be a novel targeted approach to control inflammation and minimize cell death in CPB surgery.

\section{Study Limitations}

The main limitation in our study is that the contribution of CPB versus DHCA to the observed responses cannot be determined because the piglets were exposed to both in this model. Further studies examining the effect of continuous $\mathrm{CPB}$ alone on the striatum injury are warranted in the future. Moreover, as new perfusion techniques evolve as an adjunct or alternative to DHCA, new animal models need to be developed to fully assess superiority among the techniques regarding brain injury protection. Finally, given the complexity of more than 10 cell types present in the striatum, ${ }^{35}$ it was impossible to accurately attribute certain transcriptional changes to a specific cell type, and single-cell RNA sequencing in future studies would be helpful to provide us the answer. It would also be interesting to examine other regions of the brain such as hippocampus and frontal cortex to compare their transcriptional responses with the striatum in future studies.

\section{CONCLUSIONS}

Brain injury is a major complication in neonates undergoing cardiac bypass surgeries. Our study provided a comprehensive view of global transcriptional changes in the striatum, one of the most vulnerable brain regions, after CPB and DHCA. We found strong activation of both inflammatory and apoptotic signaling pathways in the DHCA group 6 hours after surgery. NF-kB, a key driver of inflammation, appears to be an upstream regulator of the majority of the upregulated genes; hence, NF-kB inhibitors could potentially be tested for beneficial effects on neurologic outcome.

\section{Conflict of Interest Statement}

Authors have nothing to disclose with regard to commercial support.

\section{References}

1. Shillingford AJ, Glanzman MM, Ittenbach RF, Clancy RR, Gaynor JW, Wernovsky G. Inattention, hyperactivity, and school performance in a population of school-age children with complex congenital heart disease. Pediatrics. 2008; 121:e759-67.

2. Forbess JM, Visconti KJ, Hancock-Friesen C, Howe RC, Bellinger DC, Jonas RA. Neurodevelopmental outcome after congenital heart surgery: results from an institutional registry. Circulation. 2002;106:I95-102.

3. Andropoulos DB, Brady KM, Easley RB, Fraser CD Jr. Neuroprotection in pediatric cardiac surgery: what is on the horizon? Prog Pediatr Cardiol. 2010 29:113-22.

4. Amir G, Ramamoorthy C, Riemer RK, Reddy VM, Hanley FL. Neonatal brain protection and deep hypothermic circulatory arrest: pathophysiology of ischemic neuronal injury and protective strategies. Ann Thorac Surg. 2005;80:1955-64. 
5. Kurth CD, Priestley M, Golden J, McCann J, Raghupathi R. Regional patterns of neuronal death after deep hypothermic circulatory arrest in newborn pigs. J Thorac Cardiovasc Surg. 1999;118:1068-77.

6. Pastuszko P, Schears GJ, Greeley WJ, Kubin J, Wilson DF, Pastuszko A Granulocyte colony stimulating factor reduces brain injury in a cardiopulmonary bypass-circulatory arrest model of ischemia in a newborn piglet. Neurochem Res. 2014;39:2085-92.

7. Ditsworth D, Priestley MA, Loepke AW, Ramamoorthy C, McCann J, Staple L, et al. Apoptotic neuronal death following deep hypothermic circulatory arrest in piglets. Anesthesiology. 2003;98:1119-27.

8. Pastuszko P, Schears GJ, Pirzadeh A, Kubin J, Greeley WJ, Wilson DF, et al. Effect of granulocyte-colony stimulating factor on expression of selected proteins involved in regulation of apoptosis in the brain of newborn piglets after cardiopulmonary bypass and deep hypothermic circulatory arrest. J Thorac Cardiovasc Surg. 2012;143:1436-42.

9. Dobin A, Davis CA, Schlesinger F, Drenkow J, Zaleski C, Jha S, et al. STAR: ultrafast universal RNA-seq aligner. Bioinformatics. 2013;29:15-21.

10. Liao Y, Smyth GK, Shi W. featureCounts: an efficient general purpose program for assigning sequence reads to genomic features. Bioinformatics. 2014;30:923-30.

11. Love MI, Huber W, Anders S. Moderated estimation of fold change and dispersion for RNA-seq data with DESeq2. Genome Biol. 2014;15:550.

12. Gorgens SW, Benninghoff T, Eckardt K, Springer C, Chadt A, Melior A, et al. Hypoxia in combination with muscle contraction improves insulin action and glucose metabolism in human skeletal muscle via the HIF-1alpha pathway. Diabetes. 2017;66:2800-7.

13. Hackenbeck T, Huber R, Schietke R, Knaup KX, Monti J, Wu X, et al. The GTPase RAB20 is a HIF target with mitochondrial localization mediating apoptosis in hypoxia. Biochim Biophys Acta. 2011;1813:1-13.

14. Li R, Chen W, Yanes R, Lee S, Berliner JA. OKL38 is an oxidative stress response gene stimulated by oxidized phospholipids. J Lipid Res. 2007;48: 709-15.

15. Yao H, Li P, Venters BJ, Zheng S, Thompson PR, Pugh BF, et al. Histone Arg modifications and p53 regulate the expression of OKL38, a mediator of apoptosis. J Biol Chem. 2008;283:20060-8.

16. Hu J, Yao H, Gan F, Tokarski A, Wang Y. Interaction of OKL38 and p53 in regulating mitochondrial structure and function. PLoS One. 2012;7:e43362.

17. Du K, Herzig S, Kulkarni RN, Montminy M. TRB3: a tribbles homolog that inhibits Akt/PKB activation by insulin in liver. Science. 2003;300:1574-7.

18. Kumada M, Niwa M, Hara A, Matsuno H, Mori H, Ueshima S, et al. Tissue type plasminogen activator facilitates NMDA-receptor-mediated retinal apoptosis through an independent fibrinolytic cascade. Invest Ophthalmol Vis Sci. 2005; 46:1504-7.

19. Lee HS, Woo SJ, Koh HW, Ka SO, Zhou L, Jang KY, et al. Regulation of apoptosis and inflammatory responses by insulin-like growth factor binding protein 3 in fibroblast-like synoviocytes and experimental animal models of rheumatoid arthritis. Arthritis Rheumatol. 2014;66:863-73.

20. Moore F, Santin I, Nogueira TC, Gurzov EN, Marselli L, Marchetti P, et al. The transcription factor C/EBP delta has anti-apoptotic and anti-inflammatory roles in pancreatic beta cells. PLoS One. 2012;7:e31062.
21. Oguchi ME, Etoh K, Fukuda M. Rab20, a novel Rab small GTPase that negatively regulates neurite outgrowth of PC12 cells. Neurosci Lett. 2018;662: 324-30.

22. Caldarone CA, Barner EW, Wang L, Karimi M, Mascio CE, Hammel JM, et al. Apoptosis-related mitochondrial dysfunction in the early postoperative neonatal lamb heart. Ann Thorac Surg. 2004;78:948-55.

23. Mahle WT, Matthews E, Kanter KR, Kogon BE, Hamrick SE, Strickland MJ. Inflammatory response after neonatal cardiac surgery and its relationship to clinical outcomes. Ann Thorac Surg. 2014;97:950-6.

24. Finn A, Naik S, Klein N, Levinsky RJ, Strobel S, Elliott M. Interleukin-8 release and neutrophil degranulation after pediatric cardiopulmonary bypass. J Thorac Cardiovasc Surg. 1993;105:234-41.

25. Nussmeier NA, Searles BE. Inflammatory brain injury after cardiopulmonary bypass: is it real? Anesth Analg. 2010;110:288-90.

26. Merino JG, Latour LL, Tso A, Lee KY, Kang DW, Davis LA, et al. Blood-brain barrier disruption after cardiac surgery. AJNR Am J Neuroradiol. 2013;34: 518-23.

27. Trakas E, Domnina Y, Panigrahy A, Baust T, Callahan PM, Morell VO, et al. Serum neuronal biomarkers in neonates with congenital heart disease undergoing cardiac surgery. Pediatr Neurol. 2017;72:56-61.

28. Chen K, Sun Y, Diao Y, Ji L, Song D, Zhang T. alpha7 nicotinic acetylcholine receptor agonist inhibits the damage of rat hippocampal neurons by TLR4/Myd88/NFkappaB signaling pathway during cardiopulmonary bypass. Mol Med Rep. 2017; 16:4770-6.

29. Nan Z, Jin Z, Huijuan C, Tiezheng Z, Keyan C. Effects of TLR3 and TLR9 signaling pathway on brain protection in rats undergoing sevoflurane pretreatment during cardiopulmonary bypass. Biomed Res Int. 2017;2017:4286738.

30. Sui Y, Stehno-Bittel L, Li S, Loganathan R, Dhillon NK, Pinson D, et al. CXCL10-induced cell death in neurons: role of calcium dysregulation. Eur $J$ Neurosci. 2006;23:957-64.

31. Mahad DJ, Howell SJ, Woodroofe MN. Expression of chemokines in the CSF and correlation with clinical disease activity in patients with multiple sclerosis. J Neurol Neurosurg Psychiatry. 2002;72:498-502.

32. Grumont RJ, Gerondakis S. Rel induces interferon regulatory factor 4 (IRF-4) expression in lymphocytes: modulation of interferon-regulated gene expression by rel/nuclear factor kappaB. J Exp Med. 2000;191:1281-92.

33. De Smaele E, Zazzeroni F, Papa S, Nguyen DU, Jin R, Jones J, et al. Induction of gadd45beta by NF-kappaB downregulates pro-apoptotic JNK signalling. Nature. 2001;414:308-13.

34. Liu YW, Chen CC, Wang JM, Chang WC, Huang YC, Chung SY, et al. Role of transcriptional factors Sp1, c-Rel, and c-Jun in LPS-induced C/EBPdelta gene expression of mouse macrophages. Cell Mol Life Sci. 2007;64:3282-94.

35. Gokce O, Stanley GM, Treutlein B, Neff NF, Camp JG, Malenka RC, et al. Cellular taxonomy of the mouse striatum as revealed by single-cell RNA-Seq. Cell Rep. 2016;16:1126-37.

Key Words: cardiac surgery, congenital heart disease, developing brain, striatum, nuclear factor-kB 
TABLE E1. List of genes that were significantly upregulated in the striatum after deep hypothermic circulatory arrest

\begin{tabular}{|c|c|c|c|}
\hline ID & Name & FC & $\begin{array}{l}\text { Adjusted } \\
P \text { value }\end{array}$ \\
\hline CXCL9 & $\mathrm{C}-\mathrm{X}-\mathrm{C}$ motif chemokine ligand 9 & 32.4 & .042 \\
\hline CXCL10 & $\mathrm{C}-\mathrm{X}-\mathrm{C}$ motif chemokine ligand 10 & 22.2 & $<.001$ \\
\hline CCL2 & C-C motif chemokine ligand 2 & 17.6 & .001 \\
\hline TGM3 & transglutaminase 3 & 16.4 & $<.001$ \\
\hline IRF4 & interferon regulatory factor 4 & 15.6 & $<.001$ \\
\hline $\mathrm{ADM}$ & adrenomedullin & 9.6 & $<.001$ \\
\hline MT1A & metallothionein $1 \mathrm{~A}$ & 8.5 & $<.001$ \\
\hline STX11 & syntaxin 11 & 6.3 & $<.001$ \\
\hline IGFBP3 & $\begin{array}{l}\text { insulin like growth factor binding } \\
\text { protein } 3\end{array}$ & 5.8 & $<.001$ \\
\hline THBS1 & thrombospondin 1 & 5.6 & $<.001$ \\
\hline SERPINE1 & serpin family E member 1 & 5.5 & $<.001$ \\
\hline EMP1 & epithelial membrane protein 1 & 5.4 & $<.001$ \\
\hline BATF2 & $\begin{array}{l}\text { basic leucine zipper ATF-like } \\
\text { transcription factor } 2\end{array}$ & 5.0 & .001 \\
\hline $\mathrm{CD} 274$ & CD274 molecule & 4.7 & .002 \\
\hline FAM111A & $\begin{array}{l}\text { family with sequence similarity } \\
111 \text { member A }\end{array}$ & 4.6 & $<.001$ \\
\hline GEM & $\begin{array}{l}\text { GTP binding protein overexpressed } \\
\text { in skeletal muscle }\end{array}$ & 4.4 & $<.001$ \\
\hline SLA & Src like adaptor & 4.3 & $<.001$ \\
\hline CEBPD & $\begin{array}{l}\text { CCAAT enhancer binding protein } \\
\text { delta }\end{array}$ & 4.1 & $<.001$ \\
\hline OSGIN1 & $\begin{array}{l}\text { oxidative stress induced growth } \\
\text { inhibitor } 1\end{array}$ & 3.7 & .001 \\
\hline FKBP5 & FK506 binding protein 5 & 3.7 & $<.001$ \\
\hline LRRC32 & leucine rich repeat containing 32 & 3.7 & $<.001$ \\
\hline PTGS2 & $\begin{array}{l}\text { prostaglandin-endoperoxide } \\
\text { synthase } 2\end{array}$ & 3.5 & .001 \\
\hline TIFA & $\begin{array}{l}\text { TRAF interacting protein with } \\
\text { forkhead associated domain }\end{array}$ & 3.5 & .011 \\
\hline SRGN & serglycin & 3.4 & $<.001$ \\
\hline RAB20 & $\begin{array}{l}\text { RAB20, member RAS oncogene } \\
\text { family }\end{array}$ & 3.3 & $<.001$ \\
\hline TLR2 & toll like receptor 2 & 3.3 & $<.001$ \\
\hline HAVCR2 & hepatitis A virus cellular receptor 2 & 3.2 & $<.001$ \\
\hline GADD45A & $\begin{array}{l}\text { growth arrest and DNA damage } \\
\text { inducible alpha }\end{array}$ & 3.2 & $<.001$ \\
\hline MAFF & MAF bZIP transcription factor $F$ & 3.1 & .026 \\
\hline RTL9 & retrotransposon Gag like 9 & 3.1 & .004 \\
\hline GADD45B & $\begin{array}{l}\text { growth arrest and DNA damage } \\
\text { inducible beta }\end{array}$ & 3.1 & .018 \\
\hline ICAM1 & intercellular adhesion molecule 1 & 3.1 & .009 \\
\hline SLC7A2 & solute carrier family 7 member 2 & 3.1 & $<.001$ \\
\hline
\end{tabular}

TABLE E1. Continued

\begin{tabular}{|c|c|c|c|}
\hline ID & Name & FC & $\begin{array}{l}\text { Adjusted } \\
P \text { value }\end{array}$ \\
\hline OSMR & oncostatin $\mathrm{M}$ receptor & 3.1 & .003 \\
\hline TRIB3 & tribbles pseudokinase 3 & 2.9 & .015 \\
\hline PLAT & plasminogen activator, tissue type & 2.9 & $<.001$ \\
\hline EDN1 & endothelin 1 & 2.9 & .002 \\
\hline CCR1 & C-C motif chemokine receptor 1 & 2.9 & .023 \\
\hline PDK4 & pyruvate dehydrogenase kinase 4 & 2.9 & .022 \\
\hline CASP7 & caspase 7 & 2.8 & .009 \\
\hline TICAM2 & toll like receptor adaptor molecule 2 & 2.8 & .033 \\
\hline CEBPB & $\begin{array}{l}\text { CCAAT enhancer binding protein } \\
\text { beta }\end{array}$ & 2.8 & $<.001$ \\
\hline TIMP1 & TIMP metallopeptidase inhibitor 1 & 2.8 & .015 \\
\hline PIK3AP1 & $\begin{array}{l}\text { phosphoinositide-3-kinase adaptor } \\
\text { protein } 1\end{array}$ & 2.7 & $<.001$ \\
\hline CDKN1A & cyclin dependent kinase inhibitor $1 \mathrm{~A}$ & 2.7 & .026 \\
\hline RDH10 & retinol dehydrogenase 10 & 2.6 & $<.001$ \\
\hline CSF2RB & $\begin{array}{l}\text { colony stimulating factor } 2 \text { receptor } \\
\text { beta common subunit }\end{array}$ & 2.6 & .010 \\
\hline PLA2G3 & phospholipase A2 group III & 2.5 & .001 \\
\hline TNFAIP6 & TNF alpha induced protein 6 & 2.4 & .036 \\
\hline STK17B & serine/threonine kinase $17 \mathrm{~b}$ & 2.4 & .008 \\
\hline MT2A & metallothionein $2 \mathrm{~A}$ & 2.4 & $<.001$ \\
\hline SAMSN1 & $\begin{array}{l}\text { SAM domain, SH3 domain nuclear } \\
\text { localization signals } 1\end{array}$ & 2.4 & .003 \\
\hline CD14 & CD14 molecule & 2.3 & .010 \\
\hline CITED2 & carboxy-terminal domain 2 & 2.3 & .011 \\
\hline $\mathrm{CISH}$ & $\begin{array}{l}\text { cytokine inducible } \mathrm{SH} 2 \text { containing } \\
\text { protein }\end{array}$ & 2.3 & .021 \\
\hline PLAGL2 & PLAG1 like zinc finger 2 & 2.3 & $<.001$ \\
\hline CLIC2 & chloride intracellular channel 2 & 2.3 & .006 \\
\hline SPIDR & $\begin{array}{l}\text { scaffold protein involved in DNA } \\
\text { repair }\end{array}$ & 2.2 & .008 \\
\hline ACER2 & alkaline ceramidase 2 & 2.2 & $<.001$ \\
\hline ACKR3 & atypical chemokine receptor 3 & 2.2 & $<.001$ \\
\hline FZD4 & frizzled class receptor 4 & 2.2 & $<.001$ \\
\hline CCNL1 & cyclin L1 & 2.2 & .002 \\
\hline USP53 & ubiquitin specific peptidase 53 & 2.2 & .020 \\
\hline FAM83D & $\begin{array}{l}\text { family with sequence similarity } 83 \\
\text { member D }\end{array}$ & 2.2 & .035 \\
\hline SLC39A8 & solute carrier family 39 member 8 & 2.1 & .034 \\
\hline RGS2 & regulator of G protein signaling 2 & 2.1 & .008 \\
\hline RBM3 & RNA binding motif protein 3 & 2.1 & .001 \\
\hline TMEM100 & transmembrane protein 100 & 2.1 & .003 \\
\hline ZFAND5 & zinc finger AN1-type containing 5 & 2.0 & .026 \\
\hline PIM1 & $\begin{array}{l}\text { Pim-1 proto-oncogene, } \\
\text { serine/threonine kinase }\end{array}$ & 2.0 & .041 \\
\hline
\end{tabular}


TABLE E1. Continued

\begin{tabular}{|c|c|c|c|}
\hline ID & Name & FC & $\begin{array}{l}\text { Adjusted } \\
P \text { value }\end{array}$ \\
\hline SOD2 & superoxide dismutase 2 & 2.0 & .003 \\
\hline PLCD1 & phospholipase $\mathrm{C}$ delta 1 & 2.0 & .002 \\
\hline RHOJ & ras homolog family member $\mathbf{J}$ & 2.0 & $<.001$ \\
\hline TRIB1 & tribbles pseudokinase 1 & 1.9 & .022 \\
\hline ODC1 & ornithine decarboxylase 1 & 1.9 & .002 \\
\hline EFHD2 & EF-hand domain family member D2 & 1.9 & .005 \\
\hline RELL1 & RELT like 1 & 1.9 & .015 \\
\hline DDX3X & DEAD-box helicase $3 \mathrm{X}$-linked & 1.9 & .020 \\
\hline ITGA5 & integrin subunit alpha 5 & 1.9 & .021 \\
\hline GBP2 & guanylate binding protein 2 & 1.9 & .042 \\
\hline $\mathrm{CD} 38$ & CD38 molecule & 1.9 & .007 \\
\hline YBX3 & Y-box binding protein 3 & 1.9 & .023 \\
\hline TCTN3 & tectonic family member 3 & 1.9 & .001 \\
\hline MAP3K8 & $\begin{array}{l}\text { mitogen-activated protein kinase } \\
\text { kinase kinase } 8\end{array}$ & 1.9 & .050 \\
\hline GLCCI1 & glucocorticoid induced 1 & 1.8 & .035 \\
\hline EHD4 & EH domain containing 4 & 1.8 & .023 \\
\hline EMP2 & epithelial membrane protein 2 & 1.8 & $<.001$ \\
\hline CIART & $\begin{array}{l}\text { circadian associated repressor of } \\
\text { transcription }\end{array}$ & 1.8 & .009 \\
\hline ELMSAN1 & $\begin{array}{l}\text { ELM2 and Myb/SANT domain } \\
\text { containing } 1\end{array}$ & 1.8 & .043 \\
\hline IRAK2 & $\begin{array}{l}\text { interleukin } 1 \text { receptor associated } \\
\text { kinase } 2\end{array}$ & 1.8 & .042 \\
\hline PGM2 & phosphoglucomutase 2 & 1.7 & .006 \\
\hline $\mathrm{ZC} 3 \mathrm{H} 12 \mathrm{C}$ & $\begin{array}{l}\text { zinc finger CCCH-type containing } \\
12 \mathrm{C}\end{array}$ & 1.7 & .022 \\
\hline LITAF & $\begin{array}{l}\text { lipopolysaccharide induced TNF } \\
\text { factor }\end{array}$ & 1.7 & .009 \\
\hline RCL1 & $\begin{array}{l}\text { RNA terminal phosphate cyclase } \\
\text { like } 1\end{array}$ & 1.7 & .003 \\
\hline FAM129A & $\begin{array}{l}\text { family with sequence similarity } 129 \\
\text { member A }\end{array}$ & 1.7 & .020 \\
\hline QTRT2 & $\begin{array}{l}\text { queuine tRNA-ribosyltransferase } \\
\text { accessory subunit } 2\end{array}$ & 1.7 & .050 \\
\hline UMPS & uridine monophosphate synthetase & 1.6 & .043 \\
\hline KLF9 & Kruppel like factor 9 & 1.6 & .024 \\
\hline C3orf70 & chromosome 3 open reading frame 70 & 1.6 & .026 \\
\hline MCL1 & $\begin{array}{l}\text { MCL1, BCL2 family apoptosis } \\
\text { regulator }\end{array}$ & 1.6 & .017 \\
\hline CEP85L & centrosomal protein 85 like & 1.6 & .026 \\
\hline $\mathrm{CDH} 5$ & cadherin 5 & 1.6 & .036 \\
\hline RCAN1 & regulator of calcineurin 1 & 1.6 & .012 \\
\hline POLR3B & RNA polymerase III subunit B & 1.6 & .037 \\
\hline RASL11B & RAS like family 11 member B & 1.6 & .010 \\
\hline
\end{tabular}

TABLE E1. Continued

\begin{tabular}{|c|c|c|c|}
\hline ID & Name & FC & $\begin{array}{l}\text { Adjusted } \\
P \text { value }\end{array}$ \\
\hline NET1 & neuroepithelial cell transforming 1 & 1.6 & .023 \\
\hline JAK3 & Janus kinase 3 & 1.6 & .012 \\
\hline STAT3 & $\begin{array}{l}\text { signal transducer and activator of } \\
\text { transcription } 3\end{array}$ & 1.6 & .001 \\
\hline PTPN1 & $\begin{array}{l}\text { protein tyrosine phosphatase, } \\
\text { non-receptor type } 1\end{array}$ & 1.5 & .011 \\
\hline ABHD4 & abhydrolase domain containing 4 & 1.5 & .007 \\
\hline FOSL2 & $\begin{array}{l}\text { FOS like 2, AP-1 transcription factor } \\
\text { subunit }\end{array}$ & 1.5 & .003 \\
\hline DDIT4 & DNA damage inducible transcript 4 & 1.5 & .042 \\
\hline PFKFB4 & $\begin{array}{l}\text { 6-phosphofructo-2-kinase/ } \\
\text { fructose-2,6-biphosphatase } 4\end{array}$ & 1.5 & .033 \\
\hline COG2 & $\begin{array}{l}\text { component of oligomeric golgi } \\
\text { complex } 2\end{array}$ & 1.5 & .036 \\
\hline $\mathrm{SSH} 2$ & slingshot protein phosphatase 2 & 1.5 & .050 \\
\hline DNAJB1 & $\begin{array}{l}\text { DnaJ heat shock protein family } \\
\text { (Hsp40) member B1 }\end{array}$ & 1.5 & .021 \\
\hline ETS2 & $\begin{array}{l}\text { ETS proto-oncogene } 2, \\
\text { transcription factor }\end{array}$ & 1.5 & .049 \\
\hline CORO1C & coronin $1 \mathrm{C}$ & 1.4 & .014 \\
\hline JAG1 & jagged 1 & 1.4 & .023 \\
\hline RAE1 & ribonucleic acid export 1 & 1.4 & .037 \\
\hline SH3BP4 & SH3 domain binding protein 4 & 1.4 & .029 \\
\hline RASAL2 & RAS protein activator like 2 & 1.3 & .030 \\
\hline TBC1D20 & TBC1 domain family member 20 & 1.3 & .036 \\
\hline
\end{tabular}


TABLE E2. List of genes that were significantly downregulated in the striatum after deep hypothermic circulatory arrest

\begin{tabular}{|c|c|c|c|}
\hline ID & Name & FC & Adjusted $P$ value \\
\hline TTR & transthyretin & 7.4 & .042 \\
\hline ALS2CL & ALS2 C-terminal like & 6.9 & $<.001$ \\
\hline FCRL1 & Fc receptor like 1 & 6.1 & .006 \\
\hline SLC52A3 & solute carrier family 52 member 3 & 5.9 & $<.001$ \\
\hline ARHGEF15 & Rho guanine nucleotide exchange factor 15 & 5.8 & .005 \\
\hline PCDH12 & protocadherin 12 & 5.7 & $<.001$ \\
\hline FOXQ1 & forkhead box Q1 & 5.7 & .034 \\
\hline CA4 & carbonic anhydrase 4 & 5.3 & .002 \\
\hline PRDM8 & PR/SET domain 8 & 5.0 & .010 \\
\hline SLC19A3 & solute carrier family 19 member 3 & 4.9 & $<.001$ \\
\hline USHBP1 & Usher syndrome $1 \mathrm{C}$ binding protein 1 & 4.3 & .001 \\
\hline FOXF2 & forkhead box F2 & 4.0 & .012 \\
\hline KRT23 & keratin 23 & 3.4 & .006 \\
\hline ZIC5 & Zic family member 5 & 3.4 & .020 \\
\hline PGGHG & protein-glucosylgalactosylhydroxylysine glucosidase & 3.2 & .006 \\
\hline ADAMTS16 & ADAM metallopeptidase with thrombospondin type 1 motif 16 & 3.2 & .042 \\
\hline FBXL13 & F-box and leucine rich repeat protein 13 & 3.1 & .042 \\
\hline HBB & hemoglobin subunit beta & 3.1 & .001 \\
\hline VWA2 & von Willebrand factor A domain containing 2 & 3.0 & .042 \\
\hline MEGF6 & multiple EGF like domains 6 & 3.0 & .005 \\
\hline NCF1 & neutrophil cytosolic factor 1 & 2.8 & .033 \\
\hline SLC22A6 & solute carrier family 22 member 6 & 2.7 & $<.001$ \\
\hline ACVRL1 & activin A receptor like type 1 & 2.6 & $<.001$ \\
\hline SEMA3G & semaphorin $3 \mathrm{G}$ & 2.6 & $<.001$ \\
\hline GPAT3 & glycerol-3-phosphate acyltransferase 3 & 2.6 & .019 \\
\hline NES & nestin & 2.5 & .004 \\
\hline RASAL3 & RAS protein activator like 3 & 2.5 & $<.001$ \\
\hline ALOX15 & arachidonate 15-lipoxygenase & 2.5 & .005 \\
\hline $\mathrm{NR} 2 \mathrm{~F} 2$ & nuclear receptor subfamily 2 group $\mathrm{F}$ member 2 & 2.4 & .021 \\
\hline EGF & epidermal growth factor & 2.4 & .008 \\
\hline EFCC1 & EF-hand and coiled-coil domain containing 1 & 2.4 & .009 \\
\hline RARG & retinoic acid receptor gamma & 2.3 & $<.001$ \\
\hline MILR1 & mast cell immunoglobulin like receptor 1 & 2.3 & .020 \\
\hline PIK3R6 & phosphoinositide-3-kinase regulatory subunit 6 & 2.3 & .015 \\
\hline LEF1 & lymphoid enhancer binding factor 1 & 2.3 & .004 \\
\hline FAM83H & family with sequence similarity 83 member $\mathrm{H}$ & 2.2 & .021 \\
\hline SLC16A4 & solute carrier family 16 member 4 & 2.2 & $<.001$ \\
\hline PTPN14 & protein tyrosine phosphatase, non-receptor type 14 & 2.2 & .044 \\
\hline CPT1B & carnitine palmitoyltransferase $1 \mathrm{~B}$ & 2.1 & .007 \\
\hline $\mathrm{NR} 2 \mathrm{~F} 1$ & nuclear receptor subfamily 2 group $F$ member 1 & 2.1 & .026 \\
\hline ARHGAP27 & Rho GTPase activating protein 27 & 2.1 & .001 \\
\hline THSD1 & thrombospondin type 1 domain containing 1 & 2.1 & .001 \\
\hline APCDD1 & APC down-regulated 1 & 2.1 & .012 \\
\hline ARAP3 & ArfGAP with RhoGAP domain, ankyrin repeat and PH domain 3 & 2.0 & .005 \\
\hline
\end{tabular}


TABLE E2. Continued

\begin{tabular}{|c|c|c|c|}
\hline ID & Name & FC & Adjusted $P$ value \\
\hline ZBTB40 & zinc finger and BTB domain containing 40 & 2.0 & .001 \\
\hline HSPA12B & heat shock protein family A (Hsp70) member 12B & 2.0 & .011 \\
\hline GPR17 & G protein-coupled receptor 17 & 1.9 & .036 \\
\hline SERPINH1 & serpin family $\mathrm{H}$ member 1 & 1.9 & .017 \\
\hline GNAS & GNAS complex locus & 1.9 & .010 \\
\hline FES & FES proto-oncogene, tyrosine kinase & 1.9 & .020 \\
\hline CEP164 & centrosomal protein 164 & 1.9 & .022 \\
\hline SLC46A3 & solute carrier family 46 member 3 & 1.9 & .033 \\
\hline PCDH18 & protocadherin 18 & 1.9 & .001 \\
\hline ADAMTS10 & ADAM metallopeptidase with thrombospondin type 1 motif 10 & 1.8 & .026 \\
\hline ITPR3 & inositol 1,4,5-trisphosphate receptor type 3 & 1.8 & .018 \\
\hline PHLDA1 & pleckstrin homology like domain family A member 1 & 1.8 & .042 \\
\hline CD34 & CD34 molecule & 1.8 & .004 \\
\hline TRAF3IP3 & TRAF3 interacting protein 3 & 1.7 & .042 \\
\hline FGF11 & fibroblast growth factor 11 & 1.7 & .024 \\
\hline MAF & MAF bZIP transcription factor & 1.7 & .015 \\
\hline LRRK1 & leucine rich repeat kinase 1 & 1.7 & .009 \\
\hline PTPN6 & protein tyrosine phosphatase, non-receptor type 6 & 1.7 & .036 \\
\hline FAM84B & family with sequence similarity 84 member B & 1.7 & .042 \\
\hline $\mathrm{CDC} 7$ & cell division cycle 7 & 1.6 & .036 \\
\hline ABCC5 & ATP binding cassette subfamily $\mathrm{C}$ member 5 & 1.6 & .003 \\
\hline ZNF449 & zinc finger protein 449 & 1.6 & .049 \\
\hline FMNL3 & formin like 3 & 1.6 & .006 \\
\hline LAMA1 & laminin subunit alpha 1 & 1.6 & .042 \\
\hline SLCO2B1 & solute carrier organic anion transporter family member $2 \mathrm{~B} 1$ & 1.5 & .009 \\
\hline SALL1 & spalt like transcription factor 1 & 1.5 & .015 \\
\hline HYLS1 & HYLS1, centriolar and ciliogenesis associated & 1.5 & .020 \\
\hline RBM5 & RNA binding motif protein 5 & 1.4 & .002 \\
\hline PRKDC & protein kinase, DNA-activated, catalytic subunit & 1.3 & .011 \\
\hline
\end{tabular}

